Nurumbetova Sadoqat Allayarovna

Teacher of the Forensic expertise department of the Academy of the Ministry of Internal Affairs of the Republic of Uzbekistan, major

\title{
IMPROVEMENT OF PROVIDING WITH RESOURCES OF THE FORENSIC EXPERT SERVICE OFFICERS' ACTIVITY IN HOLDING TRACEOLOGY RESEARCH
}

Annotation. The article analyzes theoretical and practical problems of traceology research held by forensic expert service officers and some recommendations on their elaboration were worked out.

Key words: information, material technics, resource, normative requirements.

$$
\begin{aligned}
& \text { Нурумбетова Садоқ̧ат Аллаяровна } \\
& \text { Узбекистон Республикаси Ички ишлар } \\
& \text { Вазирлиги Академияси Криминалистик } \\
& \text { экспертизалар кафедраси ууқитувчиси, } \\
& \text { майор }
\end{aligned}
$$

\section{ЎЗБЕКИСТОНДА ТРАСОЛОГИК ТАДҚИҚОТЛАРНИ ЎТКАЗИШДА ЭКСПЕРТ-КРИМИНАЛИСТИКА ХИЗМАТИ ХОДИМЛАРИ ИШ ФАОЛИЯТИНИ РЕСУРСЛАР БИЛАН ТАЪМИНЛАШНИ ТАКОМИЛЛАШТИРИШ}

Аннотация. Мақолада эксперт-криминалистик фаолияти ходимлари томонидан ўтказиладиган трасологик тадқиқотларни ўтказишдаги назарий ва амалий муаммолар тахлил қилинган ва уларни бартараф этиш юзасидан тавсиялар берилган.

Таянч тушунчалар: ахборот, моддий техника, ресурс, меьёрий талаблар.

Нурумбетова Садокат Аллаяровна

Преподаватель кафедры

Криминалистических экспертиз Академии Министерства внутренних дел Республики Узбекистан майор

УСОВЕРШЕНСТВОВАНИЕ ОБЕСПЕЧЕНИЯ РЕСУРСАМИ СЛУЖЕБНОЙ ДЕЯТЕЛЬНОСТИ СОТРУДНИКОВ ЭКСПЕРТНОКРИМИНАЛИСТИЧЕСКОЙ СЛУЖБЫ ПРИ ПРОВЕДЕНИИ ТРАСОЛОГИЧЕСКИХ ИССЛЕДОВАНИЙ В УЗБЕКИСТАНЕ 
Аннотация. В статье анализированы теоретические и практические проблемы при проведении трасологических исследований проводимые со стороны сотрудников экспертно-криминалистической деятельности и даны рекомендации по их устранению.

Ключевые слова: информачия, материальная техника, ресурс, нормативные требования.

Wide scale reforms being held in our country today directed to meeting the demands of creation of legal system, democratic state and building of civil society is quite significant. Thus, the Law "On forensic expert" of the Republic of Uzbekistan, and the Presidential Decree № 4125 "On improvement of the activity of forensic expert" on January 17, 2019 by the President Shavkat Mirziyoyev are devoted to enhance the quality of this sphere to the new step, and play extensive role in organization of forensic expert and their legal control in the court process.

Some related articles of the Criminal-procedure, Civil-procedure, Householdprocedure and administrative responsibility Codes of the Republic of Uzbekistan, as well as some official-legal documents were used in the court of law until the acceptance of this law.

These normative-legal documents in some cases used as an "iterative and could not regulate several legal issues"1. S.A. Smirnova states that, there were some confusion and differentiation in choosing appropriate tactics and methods for expert conduction in the activities of expert establishments under various ministries $^{2}$. For this reason, there could be some difficulties in explanation of the terms related with the regulation of forensic expert activity due to the absence of unique system. As a consequence, there may be observed some problems with effectively using special terms, definitions and methodology and their systematization in the practical activities of law enforcement bodies.

\footnotetext{
${ }^{1}$ See: Khafizov Sh. N. On activity of the normative-legal regulation of forensic expert Advocate. , 2007. - № 5. - Pp. 58-61.

${ }^{2}$ See: Smirnova S. A. Forensic expertise in foreign XXI century. Condition, development, problems. Second edition, revised and completed version. - St Ptb: Petersburg, 2004. - P. 583.
} 
In the management subject, "the function of provision resources for executives is highlighted as one of the management function of the cadre-related resources of the internal affairs organs"3.

B.Z. Milner mentions that, "the function of provision resources for executives is - the management function in order to submit their authoritive duties, as well as planned tasks, once-used informational resources for effectively task implementation, material-technical, financial and other resources"4.

It is convinced that, expert-criminalitics as the highly-qualified specialists in this field use technical-criminalistics and operative-technical means in the implementation of provision fighting against crime, crime prevention, investigating the crimes with high quality and acceleration, investigative acts and operativesearch events.

Although, the main functions of the forensic expert-criminalistics of the internal affairs bodies of the Republic of Uzbekistan are to supply with scientifictechnical means of fighting against crime, methods and special competency in the following directions: research and expertise evidence and traces, criminalistic accounts, carrying out cartotecs and collections, operative-search events, provision of scientific-technical means of all types of investigative actions.

Therefore, it is important to provide with proper labor resources the activity of the staff of forensic experts. It is essential to mention that, the provision of resources for expert-traceologists is the managerial function that includes the submission of authoritive duties of the staffs, as well as the planned tasks, onceused informational material-technical, financial and other resources for effectively task implementation.

Improvement of providing with resources of the forensic expert service officers' activity in holding traceology research may be improved in accordance with the following stages:

${ }^{3}$ See: Muxammadaliyev D.S. Managerial activity of the internal affairs organs. Part 1: Textbook. T.: The Academy of the MIA of the Republic of Uzbekistan, 2012. - p 73.

${ }^{4}$ See: Milner B.Z. Organizational theory. - M., 2004. - p. 148. 
1. To define the necessity of the forensic experts to informational, technical, financial and other resources;

2. To clarify various regulative policy in expert examination;

3. To compare the typical necessity of the resources of traceological researches with other types of expertise, their informational, materialtechnical, financial and other characteristics;

4. To analyze the necessities of the forensic-experts and their limitation;

5. To supply forensic experts with sufficient electron information, materialtechnical, financial and other resources in order to further fruitful activation of them.

In the process of accounting forensic-experts' informational, materialtechnical, financial and other resources the chiefs of the forensic-expert services while revising their organizational activities have to take into consideration the typical necessities of this servicemen.

It would be more effective if the chiefs of the forensic-expert services acquire other expert-criminalists` practice, or juxtapose positive foreign experiences into process or to implement the current requirements of our law practice for supply resources in this sphere.

In this case, the quality and quantity characteristics of the resources (including information, material-technique, finance and so forth) should be taken into account with purpose of implementing the activity of forensic experts so efficiently.

Commonly, it can be considered that, the resources are sufficient which is undoubted to be successful and do not reflect to the forensic experts' activity or influence experts` activity to get worse.

In the daily routine activity of the forensic experts to work effectively and fruitful, the precise necessities of their needs, to what extent do they need (normative requirements) should be clarified, furthermore, it gives an opportunity to analyze various situations in details on the basis of the process of daily work. Forensic experts commonly face different working conditions, nonstandard and 
used as different as signed situations with the resources which are intensive or inappropriate. That's why, in the activities of forensic experts the same quality but more quantity resources, or the same quantity but more quality resources are required.

By all means, it is somehow difficult to compare the accurate necessity of the need resources of the expert-criminalists` daily routine, as well as informational, material-technical, financial and other resources with the sufficient typical one.

The reason is that, expert-criminalists come across unexpectedly with difficult nonstandard situations in their working procedures. Thereby, the conclusion of the chiefs of expert-criminalistics service in comparison usually have the possibility characterization owing to the different necessities of the resources of forensic experts in informational, material-technical, financial and other sufficient resources. This may reflect to the further actions of the chiefs of forensic experts' activity in the process of provision of the resources of the system.

Sufficiency of the forensic experts, accurate needs and necessities can be carried out as the first stage or by the form of exchanging experiences. However, if there no effective experience or norms, the process of tracological researches become difficult. In this matter, the chiefs of the forensic expert service support the specialists` concepts or on the basis of their personal life experiences.

The total amount of incidence of the resources such as informational, material-technical, and financial etc and their sufficiency may be resolved by the high rank authorities according to the applications and notifications.

According to the rule, if the applications and notifications are resolved positively, the implementation of such documents is submitted to the organizational structure which implements the function of provision directly in order to enable its execution. Sufficient provision makes the activity of the forensic experts to maintain effectively. 